\title{
Professor Werner Franke, an inspired and inspiring personality. Forever young, forever friends
}

\author{
Maya Simionescu ${ }^{1}$
}

Published online: 3 January 2020

(C) Springer-Verlag GmbH Germany, part of Springer Nature 2020

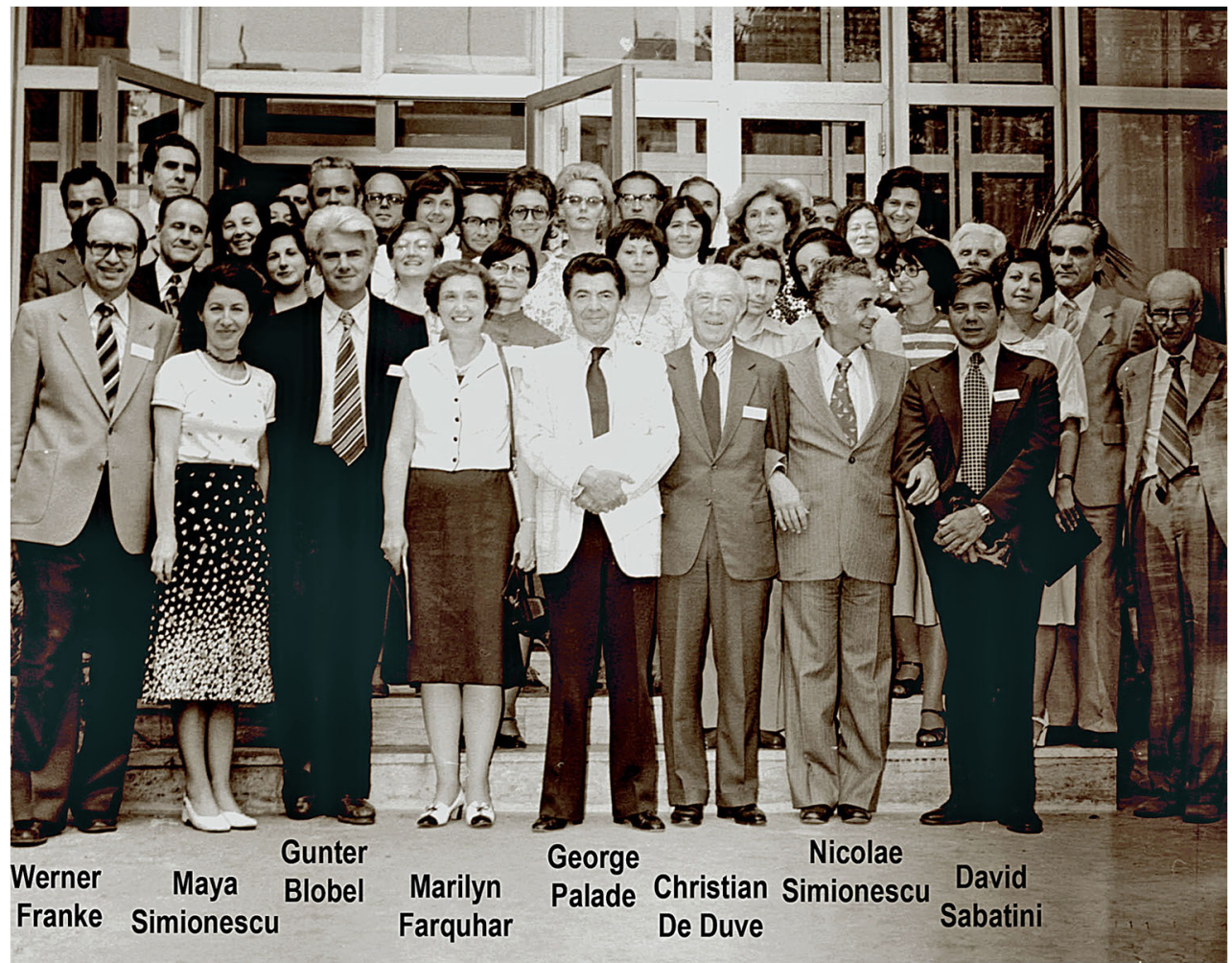

It was the year 1979. We, Prof. Nicolae Simionescu and I, were busy to organise the official opening of our new Institute of Cell Biology and Pathology (ICBP) in Bucharest. We decided to organise a workshop, and to invite, from USA, the well-known scientists such as George Palade, Gunther Blobel, Christian de Duve, Marilyn Farquhar and

Maya Simionescu

maya.simionescu@icbp.ro

Institute of Cellular Biology and Pathology "N. Simionescu”, 8, B.P. Hasdeu Street, P.O. Box 35-14, Bucharest, Romania
David Sabatini, all of them our good friends. In addition, we invited a young, well-known and highly promising cell biologist from Germany, Dr. Werner Franke (see photograph).

He came and he delivered an excellent speech on 'Cytoskeletal proteins: fibrillar and non-fibrillar'. The discussions and crucial remarks were enough for us to like greatly this young man with a kind face, an intense and passionate voice and a good sense of humour. Immediately, we become friends. It was that kind of profound friendship that resists the time and the space.

We liked him as a scientist, as a human being, as a person who cannot stay aside, but rather gets involved in many of the societal problems. 
As a scientist, he made major contributions to the modern cell and molecular biology and in particular, he uncovered the secrets of the way the cells hold together, how they use their cytoskeleton and how they organise their junctions so as to serve their functions. His papers and his micrographs are a clear blend of science and art. I was fortunate to be together with Werner at many scientific meetings in Bucharest and in Heidelberg. I admire his endless curiosity, fairness, hard work and, in particular, his joy to discover the 'undiscovered'.

As a human being, Werner Franke is an efficient, imaginative and optimist fellow, always ready to provide help and hope for his students, collaborators, friends and the new generations of scientists.

As mentioned above, Professor Werner Franke cannot be indifferent to the societal life.

I will mention just two examples. Together with his remarkable wife, Brigitte Berendonk, once an Olympic discus thrower, he has fought fervently against drug abuse in sports. As an expert in performance-enhancing drugs, among other things, he revealed the systematic use of doping by East German athletes.

A second example is the dedication and commitment of Werner Franke, to the 'Cell and Tissue Research' journal, as Section Editor for Molecular Cell Biology. He served the
Journal and the scientific community for many years and his scientific and managerial talent, plus lots of enthusiasm was put to work for this excellent scientific journal that we all praise for the quality and the value of its published papers. Certainly, in part, the value of the Journal is due to its Editors.

In conclusion, I could say that Prof. Werner Franke is an inspired and inspiring personality.

A true friend who is next to you when needed, who expresses an optimism for life, a man for whom science is his playground, that he serves with honesty, integrity and fairness.

All these qualities attracted many friends from all over the world, including many from Romania, like me, Nicolae Simionescu, and our team.

Dear Werner, be happy, stay well, be forever young and continue to enjoy science and life for many more years to come.

Yours, forever friend,

Maya Simionescu and the ICBP team

Member of the Romanian Academy

Institute of Cellular Biology and Pathology "Nicolae Simionescu"

Bucharest, Romania 